\title{
Open Borders, Unlocked Cultures
}

Romanian Roma Migrants in Western Europe

\section{Edited by Yaron Matras and Daniele Viktor Leggio}

First published 2018

ISBN: 978-1-138-23948-7 (hbk)

ISBN: 978-1-315-29577-0 (ebk)

\section{Community identity and} mobilisation

Roma migrant experiences in Manchester*

Yaron Matras and Daniele Viktor Leggio

(CC BY-NC-ND 4.0)

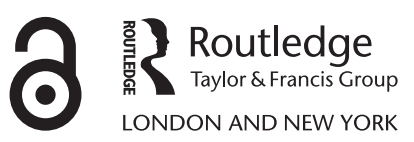





\title{
7 Community identity and mobilisation
}

\author{
Roma migrant experiences in \\ Manchester*
}

\author{
Yaron Matras and Daniele Viktor Leggio
}

\section{Introduction}

Romani political mobilisation is now an established part of the civil society landscape across Europe. It has given rise to various forms of political participation, with Romani NGOs taking up consultative roles in a number of countries, as well as in inter-governmental organisations. Models of direct political representation of Roma through a kind of quota system exist at the level of local government in Hungary and in the national elections in Romania, and a number of parliamentarians of Romani background have held direct mandates in national legislatives and in the European Parliament (cf. Klímová 2002; Fosztó 2003; McGarry 2010; Rővid 2011; Matras 2013).

Romani political activism has been labelled variously as 'Romani nationalism' (Hancock 1991; Kapralski 1997); 'Romani movement' (Matras 1998; Puxon 2000; Fosztó 2003; Vermeersch 2006; Rostas 2009; Trehan \& Kóczé 2009); 'Romani representation' (Klímová 2002; Klímová-Alexander 2010; McGarry 2010); 'Romani/Gypsy politics' (Acton 1974; Sigona \& Trehan 2009; van Baar 2013; Bunescu 2014); and more poetically as 'Romani voice' (KlímováAlexander 2005); and 'Gypsy struggle' (Acton 2000). There is general agreement among analysts that Romani political mobilisation resembles a nation-building process in its effort to forge a collective sense of identity by cultivating cultural symbolism such as historical memory and seeking to secure declarations of recognition from public institutions (cf. Marushiakova \& Popov 2005; Kapralski 2014; van Baar 2015). The relationship between mobilisation and constituency is often unclear, however (cf. Matras 2013). Romani NGOs usually receive their funding from sources that are external to Romani communities, such as European institutions and other multilateral organisations, national or local government agencies, or private charitable foundations (of which the most influential in the Romani sector has been George Soros's Open Society Foundations). The objective of Romani mobilisation efforts is often to reshape non-Roma's image of Roma, in particular in public institutions. Some authors have even suggested that the Romani nation-building project is itself a product of the attention given to Roma in European political institutions (cf. Vermeersch 2006; Ram 2014; McGarry 2014; Surdu \& Kovats 2015; van Baar 
2015). It has been argued that these institutions use the promotion of culture and ethnicity as a tool to address issues of deprivation and exclusion, thereby 'ethnicising' such issues.

In this chapter, we discuss a case of Romani mobilisation that is distinct in several key aspects from the political activism that has received attention so far in the research literature: It is local and centred around a group of individuals who are part of the young generation in a tight-knit community of migrants from the same town in Romania. Their mobilisation activities are a reaction to an emerging public discourse about their community, which they seek to contain rather than to enhance, and which they explicitly attempt to 'de-ethnicise'. They are backed not by government agencies, political organisations, or charitable foundations, but by an academic research project, which provides them with logistical and argumentative support. Their public engagement is anchored within their existing community structures and does not seek to forge a new interest community or to indulge in ethnic symbolism.

We address the question of whether this kind of experience bears more resemblance to social protest movements than to ethnic-national movements. We also ask what conclusions can be drawn from the partnership that enabled it about the way higher education institutions are redefining their agenda and taking on a role as brokers of community relations, and how the experience offers an opportunity for a critical reflection on so-called 'identity politics' and the balance between targeted interventions that purport to support Roma, and the inclusion of Roma in mainstream policy measures.

\section{Theorising Romani mobilisation}

\section{Romani nationalism}

Early international Romani mobilisation has been portrayed as a kind of national awakening, with much attention given by those involved in the process to the intricate details of allocation of offices and the content of statutes and resolutions of associations (cf. Hancock 1991; Puxon 2000). By contrast, Nirenberg (2009) offers a critical insider view of contemporary initiatives. He laments the general lack of accountability to any Romani constituency, the permanent competition among Romani organisations for attention and sponsorship of international policy bodies, the tendency to allocate meaningless honorary titles, and for key members to regard the main benefit of the organisation in the credentials that it awards to them rather than the work that it carries out. In a comprehensive study of the historical interactions of a Romani political initiative - the International Romani Union - with a key policy body - the United Nations - Klímová-Alexander (2005) describes how attempts by a small transnational circle of activists to introduce a new public discourse on Roma resonated surprisingly well with many of the addressees in UN agencies, but how such efforts were generally disorganised and by and large failed to make use of available opportunities. 
Some anthropologists have expressed the view that Romani political mobilisation amounts essentially to attempts by individuals to animate people of Romani background into organising themselves as a national movement, a concept that, they argue, is alien to the Romani community itself (cf. Cohn 1993; Okely 1997; Gay y Blasco 2001, 2002). The few in-depth analyses to date of Romani activists' motivations give a more differentiated picture, however. O'Keeffe (2013) describes how in the early Soviet Union a circle of individuals from Romani families of travelling performers tried to redefine their own position in the new state, which had curtailed their former livelihood. They cultivated the notion that Roma needed special support to adapt to Socialist values, aiming to obtain positions as facilitators of that effort on the state's behalf. This resulted in the state embracing the concept of a Romani nationality and lending its support to the creation of ethnic-national institutions such as Romani schools and literacy, and Romani industrial and agricultural collectives, which amounted in effect to the most far-reaching (albeit shortlived) state recognition of Romani ethnicity. Bunescu (2014), in a study of local Romani representation practices in Romania, argues that Romani political mobilisation is characterised by a hybridity that enables Roma to separate private practices from their public performance as a collective. In this respect, collective political identity is neither completely 'indigenous' nor is it entirely 'constructed', but is permeable and context-sensitive while co-existing with a separate, more guarded and private level of identity representation. This echoes some of Lemon's (2000) observations on the performance of identity among Russian Romani artists and activists.

\section{The so-called Europeanisation of Roma}

A current research trend draws heavily on the work of Vermeersch (2006), who views Romani political mobilisation as the impetus for the construction of the ethnic category of 'Roma' in the first place. Authors such as McGarry (2014), Surdu and Kovats (2015), and van Baar (2015), have referred to this process as the 'Europeanisation' of Romani identity. They suggest that unlike other minorities, Roma-related policy is framed primarily at the European level and that it is European involvement that creates an incentive and an opportunity for Romani activists to cultivate and operate within the ethnic category of 'Roma'.

There is no denying that there are contexts in which, as McGarry (2014: 769) implies, Roma ethnicity is being performed by Roma because that is what European policy is expecting of them. Perhaps the best example is the joint Council of Europe and Open Society Foundations initiative, launched in 2015, to set up a 'European Roma Institute'. At the time of writing, those known to be involved in the process are individuals who collectively identify as being of Romani background. The initiative's launch phase in the spring of 2016 focused on holocaust commemoration, a theme identified by authors such as Kapralski (1997, 2014), Marushiakova and Popov (2010), and van Baar (2015), as a key foundation of Romani political mobilisation. This suggests that the initiative's founders seem 
to regard Romani heritage as an intellectual project, to which at least some of them, it would appear, have committed as a professional career choice.

The protagonists of the mobilisation efforts in our study entertain hardly any awareness at all of the international Romani movement or of the Roma-related discourse among European political institutions. To them, the term Roma stands for various communities that they recognise as sharing language and other cultural practices; it is a category that is taken for granted rather than replicated from external (institutional or public) discourse. At the same time, their mobilisation efforts target individuals who share migration and family history, and are usually kin-related. To the extent that connections are forged with Roma of other backgrounds, they are indeed prompted and enabled through the mobilisation effort itself and serve to enhance it. Nonetheless, the idea that their identity as Roma is a product of political mobilisation opportunities or of the public political discourse around them is unlikely to resonate with them, nor would they subscribe to the idea that by entering the public discourse they are in any way reshaping or redefining their own notions of who they are.

\section{Romani mobilisation as a social protest movement}

Acton (1974) describes how mobilisation among Gypsies and Travellers in Britain in the 1960s was triggered by economic changes that curtail traditional patterns of work and travel and lead to a change in the relationship between Gypsies and the majority society, and to conflict. Lobbying for caravan sites and access to education and networking, led to the emergence of a political movement. In his assessment of that movement, Acton remains distant towards concepts of culture and ethnicity. Writing about the particular setting of British Gypsies and Travellers, for whom, until that time, an itinerant economy was a defining feature of their distinct culture, Acton regards accommodation of Gypsy economic particularities as the key to a successful policy.

A different kind of conflict is described by Matras (1998) in connection with the political mobilisation of Roma in Germany. That movement emerged in the late 1970s around the demand to reinstate the rights of those who had been stripped of their German citizenship by the Nazi regime, and to award them recognition as victims, and compensation. A second protest movement emerged in the late 1980s, calling for an end to the forced repatriation of Romani asylum seekers from Eastern Europe. Both movements resorted to public protest marches, often using holocaust commemoration sites as protest spaces to flag the continuity of exclusion and persecution, as well as to more drastic measures such as hunger strikes and occupation of public buildings and motorways, and a symbolic 'begging march for human rights', which provoked attention by questioning traditional images of 'Gypsy begging'.

While the ideological core and mobilisation tactics of the second, pro-migrant movement drew closely on the first, a political split emerged in the late 1980s. The network of organisations around the Central Council of German Sinti and Roma had succeeded in establishing itself as the officially recognised representation 
of the indigenous Romani minority, but refused to support Roma who were foreign nationals. By contrast, organisations operating around the Rom \& Cinti Union based in Hamburg extended their remit to the transnational community of Roma. The first movement was by and large successful in claiming recognition of victimhood and reparations. The second had limited success, at local and regional level, negotiating special arrangements to grant settlement rights to groups of migrants whose applications for asylum had initially been rejected. It also played a key role in putting migration and the social exclusion of Roma in Eastern Europe on the agenda of Western governments and European institutions such as the Council of Europe.

The tactics of mobilisation described by Acton (1974) and by Matras (1998) were essentially confrontational, resorting to public protest and exposure of what was presented as the inconsistencies of state institutions. Both cases can be framed as Social Movements, as defined by della Porta and Diani (1999): They show an overt expression of conflict where problems are identified as potential objects of collective action, and they turn values, interests, and ideas into action; they also offer an opportunity to examine how social and political contexts determine the Social Movement's chances of success. In the following sections, we ask whether the mobilisation of Romanian Roma in Manchester can also be framed as a (micro-level) Social Movement rather than the kind of 'ethnic awakening' or 'ethnic identity construction' discussed in various contemporary studies of Romani mobilisation.

\section{The emergence of local narratives on Roma}

\section{Defining Roma as a community}

Roma from Poland and the Czech Republic began to settle in Manchester in the mid-1990s. From 2001, Roma from Slovakia, Lithuania, Romania, and Hungary followed. These remained distinct communities and the only known links among them were forged in the context of evangelical initiatives, led by British Romani Gypsy missionary groups who made an effort to reach out to Eastern European Romani migrants.

A further group of Romanian Roma settled in Manchester after Romania joined the EU in 2007. They were related to the first 'pathfinder' families who settled in the city in 2001. Many had previously lived in Italy, France, or Spain. There, they endured an unstable residence situation due to limited access to housing and suffered repeated evictions from makeshift settlements. As a result, they had irregular access to key services such as health and education.

The initial terms of Romania's EU accession did not allow Romanian migrants to seek contractual or paid employment in the UK until 2014. Romanian Roma migrants in Manchester therefore engaged mainly in scrap-metal collection and cleaning, or worked as vendors of a local charity newspaper. This constituted self-employment and entitled them to claim state housing and child benefits to supplement their income. Access to cheap housing owned primarily 
by landlords of South Asian background in one of Manchester's deprived areas enabled access to health care and eventually also to education.

Amounting, in 2007-2009, to perhaps around 300 individuals or around 40-50 nuclear families, this community of Romanian Roma originated in the towns of Țăndărei and Feteşti in southeastern Romania and belonged to the group that calls itself Kangljari ('comb-makers', in Romanian Pieptănari), though some also adopted Ursari as a parallel group label. From 2009 onwards, they were joined by additional families belonging to the group calling itself Lingurari, originating in Mărășești in central Romania. The Lingurari, who are not Romani speakers, had contacts with the Romani-speaking Kangljari families back in Romania and followed them to Manchester. Other Romanian Roma in Manchester included families of Kalderari, Čurari and Ardžintari from various parts of the country, some of whom were attracted to Manchester because of the establishment of a Romanian Roma Pentecostal Church, run by a Kangljari family.

In 2009, Manchester's Eastern European Romani population was thus a fabric of family networks from different countries, with few if any ties among them. Even the population of Romanian Roma was layered, with various networks of contacts - some casual, some historical, some religious, and others kinship-based.

\section{The presence of Roma as a 'crisis'}

The arrival, within a short period of time, of large families with many schoolaged children, who settled in the city's Gorton area in close proximity to one another, prompted local schools to notice a rise in the number of children from Romania during 2008, though only some were aware that these new arrivals were Roma. The sudden change created unease among some residents, who complained to local councillors about the Roma's frequent use of public space in local parks and pavements, and made allegations of overcrowded housing, dumping of waste in street alleys, truancy, so-called anti-social behaviour (disturbances and loud gatherings), and even crime. These accusations were conveyed in the form of a petition, submitted on behalf of residents to the City Council, in the spring of 2009 by a local councillor affiliated with the minority opposition party. In response, Manchester City Council set up a 'Gorton South Roma Strategy Group'. Chaired by the City Council's Deputy Chief Executive, it included high-level representatives of key services including Street Management, Regeneration, Health, Social Services, Revenue and Benefits, Education, and the Police. The group met regularly over a period of almost two years. Its remit was to share information about Roma, to seek ways to actively engage with them, and to reduce tensions in the neighbourhood.

Minutes of the group's meetings illustrate how its deliberations at times reflected preconceptions about Romani culture: the perception that Roma are work-shy and keen to escape the reach of authorities, that they engage in crime, truancy, and anti-social behaviour, and that they are negligent in respect of their own wellbeing and that of their children, in particular girls (see MigRom 2015: 
28-32). Specific allegations of organised crime and tax avoidance were refuted, however, following action carried out by police and tax authorities that targeted Roma specifically. In response, the Roma Strategy Group flagged the need to confront negative perceptions of Roma by local residents. It also initiated a number of activities to actively involve Roma in neighbourhood events and in local youth centres, and to overcome obstacles in access to schools (including some schools' reluctance to admit Romani pupils). In August 2009, the City Council commissioned the Romani Project at the University of Manchester to carry out a survey among Romanian Roma in the Gorton South district and to propose an engagement strategy. The report arising from the survey (Matras, Fabeni, Leggio, \& Vránová 2009) was based on interviews in the Romani language, with Romani residents, during which they were explicitly invited to use the researchers as a conduit to present their views to the City Council. This was the only attempt to give the Romani residents, albeit indirectly, a voice in the consultation process.

Overall, Manchester City Council's approach to the arrival of Romanian Roma had every element of 'crisis management', closely mirroring typical policy reactions to Romani migration (cf. Matras 2000, 2013; van Baar 2011). The setting up of a high-level strategy group dedicated to a particular ethnic community was unprecedented in the history of Manchester, a city that generally prides itself on its multicultural diversity. In the aftermath, two distinct policy strands emerged. By 2013, the Roma Strategy had been discontinued and the City Council's official position was that Roma should fall within mainstream protocols of equal access to public services. At the same time, a group of people comprising staff of a local charity, the Black Health Agency for Equality (BHA), and staff from the International New Arrivals team within the City Council's Education Department, launched a series of interventions that targeted young people within the community of Romanian Roma (cf. Matras, Leggio, \& Steel 2015).

\section{Ethnicisation and marginality management}

The partnership had already started in 2010 and involved a team of around 5-6 City Council officers, some of them employed part-time by BHA (see Matras et al. 2015). Its first intervention targeted Pine Hill ${ }^{1}$ secondary school, which at the time enrolled around 60 Romani pupils. Mimicking the report by the University's Romani Project, the team engaged these pupils in a consultation process and published an information brochure about their experiences. The publication testifies to the team's initial enthusiasm and a commitment to inclusion, and conveys an overall positive image of the Roma. It reports that young Roma had experienced 'prejudice, racism and conflict in Manchester'. It acknowledges that Roma parents value formal education and observes: 'Most young people are excited, proud and motivated by school' ${ }^{2}$ It calls to ensure that Roma pupils are listened to and able to contribute.

As the team began to receive dedicated funding for its Roma-related work, it also started to develop a narrative of Romani culture. In a toolkit developed in 
2011 to instruct schools about Roma culture, BHA claimed that Romani children receive a name that is 'whispered by the mother, which remains secret and is used to confuse supernatural spirits', that Roma values are 'related to a higher spiritual power (Rromanipen, Rromipa or Rromanija)' - lending a mystical interpretation to what is simply an everyday Romani term for 'being Roma' or 'Romani-ness' - and that these values 'are known as Karma in India and it is here where the Romani spirituality reflects the Indian origin of the Romani people most' (see Matras et al. 2015; MigRom 2015: 34).

In 2012, the team received a grant from the EU's Lifelong Learning Programme to extend its intervention to a number of local primary schools. Subsequent reports depict the Roma as a group with particular needs that required external support. They speak of 'Roma learning styles' and claim that Roma possess 'the ability to negotiate the world without need for reading and writing', and that Roma children may therefore 'be better at memorising than other children'. They advise teachers that 'Roma rarely sit still for a long time', that 'most Roma are highly skilled at talking and listening at the same time', and that 'teachers need to be aware that if a Romani child is not talking, it is likely they are not listening!' ${ }^{3}$

The team thus created a narrative, communicated on behalf of the City Council's education services, which implied that Roma require a separate educational approach within the city's schools, one that caters to what was portrayed as their own cultural particularities and inherent abilities (and inabilities). They drafted a special 'Admissions and Induction Protocol for Roma Children', which proposed that schools should record, among other information, Roma pupils' readiness for learning, whether the Roma pupil wears their uniform regularly, and whether the pupil 'smiles and greets adults in school'; 'has the strength of fine motor control'; 'knows that words convey meaning'; and is able to 'sit appropriately for lesson duration'. ${ }^{4}$

As the EU grant was coming to an end, the team sought opportunities to prolong its funded interventions on Roma. Already in early 2012, BHA had approached Manchester City Council and warned that a reduction in its funding would have a negative impact, claiming, without substantiation, that 'there is a higher prevalence of Hepatitis A and B among Romani [sic] and also a higher prevalence of tuberculosis and asthma' (see MigRom 2015: 37). In January, 2013 BHA successfully applied for a grant from Manchester City Council's Equalities Funding Programme. In its application, it claimed that Roma girls were disengaging from education due to early marriage and teenage pregnancy. It promised to use the grant to 'develop protocols ... which will identify and track hard to reach girls' and to allow authorities to "share information regarding "at risk" young people in relation to criminal activity, school drop-out', and it proposed to set up a dedicated 'Romani Wellbeing Strategic Group' (see MigRom 2015: 38).

In November 2013, the BHA reported on its project to the City Council's Communities Scrutiny Committee. It stated that the rate of teenage pregnancies among the Roma was 'disproportionate' and that this was 'influenced by cultural expectations'. The same information was replicated again in the City Council's 
annual flagship publication, the 'State of the City Report: Communities of Interest', from May 2014. In its interim written report to the City Council, from June 2014, the BHA claimed: 'Early marriage is a rite of passage that [sic] individuals from within the Roma community are required to partake'. It concluded by stating: 'Roma in the UK and on continental Europe have developed a deeprooted mistrust of outsiders, limiting forms of interaction and engagement with social care providers'. It recommended that the BHA's remit and funding for the intervention should be extended in order to draw on the expertise and 'trusting relationships' that the BHA team had established in its own work with the Roma. At a meeting of the City Council's Young People and Children's Scrutiny Committee in June 2014, the Team Leader for International New Arrivals, working in partnership with the BHA project, reported that 'there was an issue, particularly with Roma girls disappearing after Year 9' and that 'it was difficult to track them down'. The topic 'safeguarding and attendance of Roma children' was consequently put on the committee's work programme in September 2014 and the Executive Member overseeing Children's Services was asked to report on the issue (see MigRom 2015: 38).

During the same period, the BHA was contracted by Pine Hill school to support a so-called English as an Additional Language Pathway, which in effect was a segregation mechanism for Roma pupils. It engaged two members of the Roma community as 'mentors' and introduced a special 'Roma Referral Form', which teachers were asked to fill in to flag up problems with Roma pupils. In a memo to school staff in the spring of 2014, the joint team of BHA and the City Council's International New Arrivals were quoted as saying that '[Roma] male and female students are not used to being together', and that therefore, 'Roma students can be very promiscuous and are very accepting of inappropriate sexualised behaviour from male students'; that female Roma pupils left school at the age of 13 to 'get married back in Romania'; that they were caught 'begging in Manchester City Centre'; and that weddings of female Roma 'from the age of 11' took place at a local park (see Matras et al. 2015; MigRom 2015: 54).

The narrative put forward by the BHA, with City Council funding and with the support of the City Council's education department, thus claimed that Roma culture posed a threat to the most vulnerable members of its own community, i.e. young girls; that the community was not accessible to others, and that the BHA therefore required an exclusive franchise to intervene; and that it was the city's responsibility to mandate such an intervention or risk failing in its statutory duty of care and protection. This narrative was adopted by City Council committees and by at least one school with a significant number of Roma pupils.

\section{Transformations in Roma participation}

\section{New practices as engagement capital}

van Baar (2013) describes how in the wake of emerging opportunities for funded interventions, Roma NGOs shift their role from advocacy to service provision, 
and how they then engage in trying to replicate social science methods in order to certify their expertise. The Manchester experience provides an example of a process that heads, arguably, in almost the opposite direction. Drawing on its academic expertise, a university project helps sets up a Roma engagement scheme that provides a service to the local community which eventually, confronted with an emerging public debate on Roma, gives rise to an advocacy initiative.

The original project plan for the MigRom consortium foresaw the allocation of a budget to Manchester City Council to engage outreach workers from among the members of the local community of Romanian Roma migrants. However, in late 2012, the City Council had to respond to the government's austerity measures by cutting a large number of jobs. Politically, it did not wish to be seen to be creating positions specifically for Roma while other positions were being discontinued. Consequently, the University of Manchester, the lead partner in MigRom, agreed to employ the outreach workers, in close collaboration with the City Council. This fitted well with the University of Manchester's newly launched Social Responsibility agenda, through which it committed to actively engage with local communities.

In the absence of a scripted outreach strategy, the University project's team decided to introduce weekly 'drop-in' consultation sessions for Roma that would be run by the Roma outreach workers. The sessions gradually developed into a new type of intervention. Led by Roma, they were strictly responsive to the needs of clients and explicitly non-intrusive, and were therefore preferred to the established format in which non-Roma case-workers would visit homes and carry out surveys that were often perceived as invasive. The drop-in session followed University research ethics protocols on data protection. By contrast to the BHA's declared policy of 'data sharing' (see above), it did not record or share clients' personal data, yet general statistics enabled the team to issue periodical assessments of needs and trends, such as access to employment. ${ }^{5}$

The scheme adopted an explicit policy of 'self-reliance', with the outreach workers encouraging clients to acquire skills to interact directly with local service providers. It took the view that in the longer term, the community should release itself from its dependency on targeted advice and support services. In the short term, the public message was that Roma were able to provide advice and support to their own community, and that external interventions should give priority to the building of capacity within the community itself.

The MigRom project's weekly Roma-led drop-in sessions soon became a fixture in the local Romanian Roma community. Operating from a local community centre in the Longsight district in South Manchester, it soon attracted Romanian Roma migrants from across the Greater Manchester area. Though not excluded in any way, Roma of other backgrounds did not make use of the service, an indication of how 'community' centres in this case primarily around shared background and migration history as well as religious and kinship networks. The service and its delivery thus became the initial engagement capital of a small group of emerging Roma spokespersons - those employed by the University of Manchester as outreach workers and a number of their associates who 
took on roles as youth workers and classroom support staff. It allowed them to build their reputation within the community and their relations with surrounding actors such as the City Council and the service providers with whom they interacted regularly on their clients' behalf.

\section{Scholarship and agency}

The MigRom project's title: 'The immigration of Romanian Roma to Western Europe: Causes, effects, and future engagement strategies', explicitly contains a commitment to public engagement with research. It uses the need for change to justify the need for knowledge, and declares its intention to use knowledge to support change. As described in the introduction to this volume, Roma participation was built into the project design. In Manchester, that participation included the outreach work programme, which came under the management of the University of Manchester due to the circumstances explained above.

The research project also assumed an agency role in another way. The City Council regarded the absence of overt leadership as an obstacle to engaging with the Roma community. In 2009, it had asked the Romani Project to recommend ways to set up a direct dialogue with the Roma community. To that end, the MigRom agenda built into its work plan the establishment of a 'Consultation Forum'. The project description submitted to the European Commission said: 'The [project's] outreach workers will support Council officials in setting up and running a regular consultation forum within the local Roma community which will act as a clearing house for issues with local services, authorities and nonRoma residents'. That objective had also been included into Manchester City Council's own report from 2013 on its Roma Strategy. ${ }^{6}$

The project's ambition to contribute directly to the creation of lasting structures was linked to the pilot research carried out in 2009 (Matras et al. 2009). That report identified the history, causes, and aspirations of Roma migration from Romania and thereby established a narrative for policy which argued that Roma arrived to seek in principle the same goals as other population groups, and so they can and should fall under the same protocols of needs assessment and access to service as other populations. By 2013, this narrative was adopted in the City Council's Roma Strategy report, which put 'mainstreaming' at the top of its engagement agenda with Roma. A direct link was thus established between inclusion, mainstreaming, and the setting of sustainable structures to enable direct dialogue between the local authority and the Romani community.

In this context, the University project saw itself as a broker of relationships between the community and the local authority, and as the source of evidencebased analysis on which an engagement strategy was to be based. Unlike other approaches to scholarship and agency, such as those discussed by Cox (2015) as Participatory Action Research, the project did not have an ambition to produce knowledge specifically in order to empower a social movement. Instead, it had sought to use the academic space to engage others in a dialogue that would be informed by evidence-based research. 
To that end, the project's academic staff engaged in discussions with the project's Romani outreach workers and a small group of young members of the Romanian Roma community. Initial conversations took place in October 2013, some six months after the project was launched, and led to a first public event, held at the University in November 2013, where young Roma were invited to present their views on Romani culture, alongside two guests from abroad, both prominent international figures in Romani education and culture. Later that month, the same people were invited to contribute to a news report on national television that featured the MigRom project's work. ${ }^{7}$ In their statements, the Roma emphasised that they had no conflict with others, that they felt accepted and integrated, and that being listened to was the key to integration. Another public event followed in February 2014, also held at the University, where members of the local Roma community shared a platform with a senior politician and representatives of the city's voluntary and education sectors. Through these events the University established a space in which 'ordinary' members of the Roma community - young individuals who had no formal role - had an opportunity to present their views and to try to influence the public narrative on their community.

In the aftermath of these events, the project invited young Roma to launch an informal 'Roma Leadership Group'. The group formed around the individuals who participated in the discussions with the project, and who then invited further members to join. Through this forum, the project's academic staff gave the Roma direct access to the local political discourse about them, introducing to them some of the documents produced by BHA and the City Council's International New Arrivals team and relevant minutes of Manchester City Council committee meetings. The Roma had not been aware of these documents, and they objected to the way in which their culture and community had been depicted in them. In discussions with the project staff, it was decided that they should approach local Councillors and ask for their views about Roma in general, and confront them with the City Council documents. Councillors were happy to meet with the Roma, and some even marked these meetings with photos posted on social media. But they were unable to address the Roma's objections to the narratives and referred them instead to the City Council's officers.

The group then decided to take public action to try to counteract negative images. Embracing an idea put to them by the MigRom staff, they launched a series of public 'litter-picking' events in November 2014, in which young Roma called on their neighbours of various backgrounds in a multi-ethnic neighbourhood to join them on a Saturday morning to clean the streets. The symbolism was intended to confront the prejudice articulated by residents, local media, and some local politicians that Roma were to blame for irregular dumping of waste. It also aimed at raising awareness of Roma and offering Roma an opportunity to show that they are willing and able to play a key role in improving community relations. The activity received logistic support from local community organisations and schools, who contributed equipment. The University project helped the group produce leaflets for the event, with instructions, accompanied by images, 
on waste disposal in several community languages including Romani (the leaflet was later adopted by the City Council for wider distribution). Local elected Councillors joined the activity, which, following an official University of Manchester press release, received coverage in the local press under the heading: 'Roma youngsters clean up streets in attempt to sweep away prejudice'. Members of the group were cited in the article as saying: 'We want to show that Roma are not different from other people'.

The group had by then established a reputation for community engagement; it had shown a commitment to challenge prejudice; it had opened a dialogue with local politicians to whom it made direct representations; and it demonstrated its ability to give wide dissemination to its activities and point of view. It had in effect established the capital needed to mobilise opinions in support of change. Through its public and media statements it had also established an incipient political vision, one that emphasised the similarities between Roma and other populations rather than the differences, and one that called for acceptance of Roma as mainstream citizens rather than as victims of discrimination or as carriers of a unique or 'exotic' culture.

\section{Conflict, collective action, and political responses}

Capitalising on this momentum, the Roma Leadership Group continued its meetings with local politicians and insisted on receiving answers to their objections to the narratives on Romani culture contained in publications produced or sponsored by the City Council. In response, a meeting was scheduled to take place at the Town Hall on the 1st of December 2014, at which the Roma would be able to face both elected politicians and officers from the relevant departments. The Roma were asked to send their questions in advance. They submitted a catalogue of questions, asking for clarification as to which City Council committees had been asked to discuss the Roma community; what their sources of information were; what the City Council's priorities in regard to Roma were; and how Roma could have input into the process. They also asked specifically why the City Council chose to address the issue of 'safeguarding and early marriage' particularly in connection to Roma, and listed a series of statements from City Council documents on these issues, which they considered to be inaccurate depictions of the Roma community. ${ }^{9}$

However, when they arrived at the meeting, the City Council officials refused to address the questions. Instead, the group was offered the opportunity to have input into future reports. This gave rise to considerable frustration among the group's members. Assisted by the MigRom project team, the group published an account of the meeting online, and sent it to members of the City Council. They emphasised their wish to be consulted on matters related to their community, and announced their intention to set up their own community group. They said specifically in their statement: 'These questions are important to our community and us because talking of Roma culture as dangerous for Roma girls is creating a bad image among our neighbourhood'. In this way, the group explicitly portrayed 
City Council action as potentially harmful to the Roma's own goal, already expressed through various public outlets, to be considered as equals. The group had now used its public image capital and the links that it had established with individuals in the City Council to stage a direct, albeit politely formulated confrontation with City Council policy, and had presented as an explicit objective, the wish to contain dissemination of information about their community in order to ensure equal opportunities. By making public a record of the proceedings, they mobilised the potential of public opinion in support of their cause.

In the following months, the group branded itself publicly as, 'Roma Voices of Manchester'. With support from the University project, it set up a social media presence, began a process of drafting statutes in preparation of formal registration as a Community Interest Company (an officially registered charitable organisation), hired venues for public events, and used the University's media relations apparatus to publicise them. In June 2015, Manchester City Council released a report in which it recognised Roma Voices of Manchester as a channel for direct dialogue with the Roma community. It distanced itself from the content of some of its own past reports and declared that it would not draw on 'unsubstantiated information' in the future. ${ }^{10}$ The report was presented to the City Council's Communities Scrutiny Committee in late June 2015, in the presence of some two dozen members of the Romanian Roma community who attended the public gallery. The establishment of Roma Voices of Manchester was celebrated in the same month through two public events with the participation of local Councillors and representatives of the local authority's executive department and it received press coverage and considerable attention from the local network of ethnic minority community groups.

The Roma's collective action centred around changing the perception of their community by their immediate neighbours, local officials, and media. It publicly challenged the image that Roma were responsible for littering. In closed conversations with officials, it challenged the image of Romani culture as promoting early marriage and disengagement from education. It was not accompanied by any attempt to inform the public or the officials about Romani culture or history, or to formulate an alternative narrative of Romani identity. Instead, it set out to challenge the framing of issues as 'Roma problems', thereby challenging the 'ethnicisation' of issues as the pillar of a targeted Roma policy.

\section{The conflict within}

As part of the MigRom project's effort to support the launch of a local Roma community group, it hired the services of Cherub - a Romani university graduate of southeastern European origin. Cherub had spent some of his formative years working with pro-Roma advocacy groups funded by European institutions and the Open Society Foundations in central Europe, and he continued to maintain close links with some of them. Cherub was line-managed directly by the University project and tasked with operating Roma Voices of Manchester's social media, and supporting networking with local ethnic minority NGOs. He was 
contracted to carry out this role for a number of months, and had relocated to Manchester specifically for that purpose. The rationale behind his engagement was to try to create a bridge between the local community of Roma, and the sector of international Romani activists.

However, Cherub's relationship with the group of local activists was problematic from the start. He seemed reluctant to engage with individual members of the local community or to become involved in the advice and support work. The local group, in turn, was tolerant but not enthusiastic about his proposals to engage in activities to commemorate the holocaust or to introduce ethnic iconography such as the Romani flag or nationalist-sounding slogans into the group's public events. Cherub also seemed uninterested in the conflict around the BHA's narrative on 'early marriage' and 'school disengagement', which had prompted the group to take public action in the first place. Instead, in his discussion contributions and presentations, he often adopted elements of that very narrative, insisting that one of the group's aims should be to encourage Romani parents to value education and to curb what he referred to as 'child marriage'. In his interactions with the project's academic staff, he often distanced himself from his local Romani peers and referred to their values, and to the dress codes of female Roma among them, as 'primitive', while on the other hand writing e-mails to local Police authorities with whom the Roma Voices group had been trying to establish cordial relationships, accusing them of 'police brutality' against Roma.

Ahead of the group's formal registration as a Community Interest Company (see above), Cherub insisted that only 'educated people' should assume a function on its Board of Directors. Cherub had won over the support of three local Roma, migrants of different backgrounds, who were university students, and attempted to steer the incipient Roma Voices of Manchester initiative in a new direction, explicitly disowning the community engagement work such as the drop-in consultation sessions and public campaigning that had served the group of Romanian Roma as their starting capital. When tensions emerged, he changed the passwords for the group's social media and e-mail account and blocked access to them for other group members. As the attempts to bridge the differences failed to yield results, he took his resentment publicly, circulating a letter via the group's own social media and on international electronic discussion lists of Romani activists in early November 2015. Signing the letter as 'Trustee Members, Roma Voices of Manchester Community Group', he described how he unilaterally changed the password as 'an act of rebellion against MigRom Project's excessive control and manipulation', turning his expressed anger toward his own employer, while claiming to be speaking on behalf of the Roma group, which that same employer had hired him to support. The channelling of resentment against an academic institution appeared to echo debates during the same time around the planned establishment of the European Roma Institute: various statements portrayed the planned initiative as a rebellion against academia, which was depicted as 'a stronghold of colonial, exotic, and paternalist approaches to Roma issues', claiming that the planned institute would provide 'intellectual emancipation' to Roma. ${ }^{11}$ 
The group of Romanian Roma reacted to Cherub's public intervention by posting on social media polite, yet critical responses: 'the Roma community does not want [Cherub to] represent them or help them anymore'; 'We wish all the best ... I can tell that you not represent us'. Cherub's attempt to re-constitute the group as a team of 'educated Roma' under his leadership failed, and after several weeks of negotiations, the original members of the Roma Leadership Group restored access to their social media platforms and elected a group of Directors for their community group, which they had now registered as a Community Interest Company. In a statement released on their social media and delivered to local stakeholders, they disowned Cherub and expressed regret about the confusing messages sent by him supposedly on their behalf. City Council officials followed the events with interest, anticipating a possible split within the group but emphasising that they were committed to working with those who best represented the local community.

This episode illustrates an interesting clash between two mobilisation narratives. The first, centred around the group of young Romanian Roma, regards as its main capital its connection with a local network of families and its commitment to providing a weekly service to its clients. It centres its public engagement around promoting an image of Roma as equal participants. To that end, it openly challenges established negative images of Roma, though it does so, not by accusing others of harbouring prejudice, but instead by presenting the Roma as a group that actively reaches out to its neighbours. This is expressed in all its public events, which are actively inclusive and where the only particular symbolism of Romani culture is food and music, which are there to be shared and distributed. This approach engages in confrontation with local government only when it believes that a public narrative about Roma culture risks drawing unwanted negative attention to Roma and thereby jeopardising the effort to participate as equals. It accepts the offer for support and advice from an established academic institution as long as that support is seen to be beneficial to its own aims and values.

The second, short-lived initiative centred around Cherub, banks on the personal capital of individuals in the hope that it will help those individuals gain respect and recognition as Roma spokespersons. The aspiration to gain recognition as representing Roma is promoted as an end in itself, disconnected from the needs of a specific local community and anchored instead in the wider and more abstract narrative about global discrimination and human rights. This is nicely illustrated by the choice of arguments in Cherub's open letter from November 2015, where he writes:

Consultation with our group's members about our Romani community group and people is essential to us not only because we are an independent community group, but also because our group and community members are of a Romani minority ethnic background. Human rights law recommends to parties to consult with ethnic minorities about any matter and decision concerning their wellbeing, social, political and economic development as a group of people. 
Cherub's emphasis is thus not on similarities and partnerships between Roma and neighbours, but on entitlements. This is well in line with prioritising commemoration of the holocaust and the depiction of Roma as victims. Cherub's confrontational action did not target the content of public depictions of Roma that were potentially discriminatory, but instead the involvement of a partner organisation, which he accused of 'control'. His depiction of that action as a 'rebellion' appeared to take its inspiration from the image of post-colonial ethnic-national liberation movements.

\section{Conclusion: between social movement and identity politics}

In the terms introduced by della Porta and Diani (1999) to characterise social movements, the group of young Romanian Roma in Manchester had identified the manner of portrayal of their culture in City Council documents, in particular references to alleged 'safeguarding' needs and 'early marriage', as problematic and harmful to their image and so to their prospects of blending into the fabric of the local diverse community. The lack of response to their initial requests for clarification created a conflict potential which triggered collective action in the form of direct representations, made public, to a group of City Council officials. The values and ideas that they formulated revolved around nothing else but emphasising the commonalities between Roma and their non-Roma neighbours, and demanding explicitly to end the preoccupation with allegedly distinct characteristics of Romani culture. These ideas were put into collective action in the form of public statements and events, and direct approaches to local officials, and ultimately by setting up a formal framework (a community interest company) and demanding to be consulted on the drafting of policy that relates to their community. The chances of success of their mobilisation effort hinged on the City Council's sensitivity toward public scrutiny, not least by the University's research project, but equally on the City Council's policy to support community groups in taking the initiative to respond to the needs of their own communities and acquire what the local authority narrative regards as 'resilience' capital that releases population groups from their dependency on local government, and arguably local government from the responsibility of providing long-term dedicated support.

Pontrandolfo (2014) discusses the clash between a tendency to abandon overt features of a distinct ethnicity and a preference toward invisibility on the part of a Romani community in Melfi, Italy, and trends to embrace particular images (such as nomadism), in order to partake in the politics of 'ethno-cultural recognition'. The experience of Roma Voices shows precisely how the group's action involved public representations geared toward removing ethnic-cultural images from the discussion, thus in effect aiming towards re-privatisation of the discourse on Romani identity (cf. Cools, Oosterlynck, Leggio, \& Matras forthcoming). The main objective of the group of local Roma might therefore be described as attaining a status quo by which the discussion of cultural practices belonged strictly to the private sphere, while the aim of the public debate was to ensure 
that Roma had all options open to them to participate in opportunities offered by the public sphere.

Our case study thus offers a new experience in the context of traditional dilemmas of 'identity politics'. Gamson (2014) addresses the general problem of the contradiction between mobilisation as a form of 'resistance' aimed at deconstructing boundaries, and the forging of a 'collective identity' that is both a prerequisite and a by-product of that very mobilisation. With reference specifically to Roma, both Vermeersch (2006: 229) and Marushiakova and Popov (2015) have pointed to the contradictory aspects of the policy of Roma inclusion which, by singling out Roma creates and fosters a form of exclusion. In the case discussed here, we witness an argumentative focus on inclusion and mainstream participation rather than on cultural and historical uniqueness. We see a symbolic gesture of reaching out to neighbours rather than seeking to establish mechanisms of self-protection, and a willingness to embrace external partnerships and benefit from the resources that they offer rather than regard them as objects of resistance and rebellion. Not least, the protagonists seek an opportunity to draw on a firm sense of community that is anchored in family ties and shared migration history, rather than in an abstract sense of ethnicity or nationalism. All this, we propose, offers a fresh approach to negotiating the various dilemmas of identity politics and ethnic mobilisation.

\section{Notes}

* The research leading to the present publication results from MigRom, 'The immigration of Romanian Roma to Western Europe: Causes, effects, and future engagement strategies', a project funded by the European Union's Seventh Framework Programme under the call on 'Dealing with diversity and cohesion: the case of the Roma in the European Union' (GA319901).

1 Name altered by the authors.

2 Davies, J. and Murphy, J. (2010) What's working: conversations with Manchester's Romanian Roma community living in Longsight and Levenshulme. Manchester: Manchester City Council Children's Services: International New Arrivals, Travellers and Supplementary Schools Team, p. 38. www.pharos.nl/documents/doc/whatsworking-conversations_roma_manchester.pdf.

3 Murphy, J. (2013) What's working for Roma in school. A network learning book. In Partnership with six Manchester Schools. Manchester: Ahmed Iqbal Ullah Education Trust, pp. 34-39, 81-83.

4 Lifelong Learning Programme Key Activity 1 Compendium 2011, pp. 4-5. See http://eacea.ec.europa.eu/llp/results_projects/documents/roma_compendium_en.pdf. Last accessed 10 March 2015.

5 For example, see http://migrom.humanities.manchester.ac.uk/wp-content/uploads/ 2015/08/MigRom-Briefing-June-2015.pdf.

6 Roma Strategy 2011-2014. Elaine Mills and Andy Wilson, Manchester City Council Chief Executive's Department, March 2013. See http://migrom.humanities.manchester. ac.uk/wp-content/uploads/2015/08/MCCRomaReport2013.pdf.

7 See: www.channel4.com/news/uk-immigrations-migrants-roma-eu.

8 See: http://migrom.humanities.manchester.ac.uk/wp-content/uploads/2015/08/MEN article.png.

9 See full documentation of the questions and the meeting here: http://migrom.humanities. manchester.ac.uk/wp-content/uploads/2015/08/Consultation-Forum.pdf. 
10 See: http://migrom.humanities.manchester.ac.uk/wp-content/uploads/2015/08/5._Roma engagement_report.pdf; also: www.manchester.gov.uk/meetings/meeting/2399/ disestablished_communities_scrutiny_committee.

11 See: www.opensocietyfoundations.org/voices/two-milestones-put-romani-culturaldiscourse-hands-roma-themselves?cb.

\section{References}

Acton, T. A. (1974) Gypsy politics and social change. London: Routledge.

Acton, T. A. (ed.) (2000) Scholarship and the Gypsy struggle. Commitment in Romani studies. Hatfield: University of Hertfordshire Press.

Bunescu, I. (2014) Roma in Europe. The politics of collective identity formation. London: Ashgate.

Cohn, W. (1993) The myth of Gypsy nationalism. Nationalities Papers, 21:2, 281-286.

Cools, P., Oosterlynck, S., Leggio, D. V., \& Matras, Y. (forthcoming) Social innovation, 'parity of participation' and the politics of needs interpretation: Engagement with Roma migrants in Manchester.

Cox, L. (2015) Scholarship and activism. A social movements perspective. Studies in Social Science 9, 34-53.

della Porta, D. \& Diani, M. (1999/2006) Social movements: An introduction. Oxford: Blackwell.

Fosztó, L. (2003) Diaspora and nationalism: An anthropological approach to the international Romani movement. Region 6:1, 102-120.

Gamson, J. (2014) The dilemma of identity politics. In Goodwin, J. \& Jasper, J. M. (eds) The social movements reader. Cases and concepts (pp. 351-362). Oxford: Wiley Blackwell.

Gay y Blasco, P. (2001). 'We don't know our descent': How the Gitanos of Jarana manage the past. Journal of the Royal Anthropological Institute, 7:4, 631-647.

Gay y Blasco, P. (2002) Gypsy/Roma diasporas: Introducing a comparative perspective. Social Anthropology, 10:2, 173-188.

Hancock, I. (1991) The East European roots of Romani nationalism. Nationalities Papers 19:3, 251-267.

Kapralski, S. (1997) Identity building and the Holocaust: Roma political nationalism, Nationalities Papers, 25:2, 269-283.

Kapralski, S. (2014). Memory, identity, and Roma transnational nationalism. In De Cesari, C. \& Rigney, A. (eds) Transnational memory (pp. 195-217). Berlin: De Gruyter.

Klímová, I. (2002) Romani political representation in Central Europe. An historical survey. Romani Studies, 12:2, 103-147.

Klímová-Alexander, I. (2005) The Romani voice in world politics. Aldershot: Ashgate.

Klímová-Alexander, I. (2010) The development and institutionalization of Romani representation and administration. Part 3c: Religious, governmental, and nongovernmental institutions (1945-1970). Nationalities Papers, 38:1, 105-122.

Lemon, A. (2000) Between two fires. Gypsy performance and Romani memory from Pushkin to post-socialism. Durham: Duke University Press.

Marushiakova, E. \& Popov, V. (2005) The Roma - a nation without a state? Historical background and contemporary tendencies. In Burszta, W., Kamusella, T., \& Wojciechowski, S. (eds) Nationalism across the globe: An overview of the nationalism of state-endowed and stateless nations. (pp. 433-455). Poznan: School of Humanities and Journalism. 
Marushiakova, E. \& Popov, V. (2010) Holocaust, Porrajmos, Samudaripen ... Tworzenie nowej mitologii narodowej. Studia Romologica, 3, 75-94.

Marushiakova, E. \& Popov. V. (2015) European policies for social inclusion of Roma: Catch 22? Social Inclusion, 3:5, 19-31.

Matras, Y. (1998) The development of the Romani civil rights movement in Germany 1945-1996. In Tebutt, S. (ed.) Sinti and Roma in German-speaking society and literature (pp. 49-63). Oxford: Berghahn.

Matras, Y. (2000) Romani migrations in the post-communist era: Their historical and political significance. Cambridge Review of International Affairs, 12:2, 32-50.

Matras, Y. (2013) Scholarship and the politics of Romani identity: Strategic and conceptual issues. European Yearbook of Minority Issues, 10: 209-245

Matras, Y., Fabeni, G. B., Leggio, D. V., \& Vránová, E. (2009) The Roma community in Gorton South, Manchester. Manchester: The University of Manchester. See http:// romani.humanities.manchester.ac.uk/downloads/2/report.pdf.

Matras, Y., Leggio, D. V., \& Steel, M. (2015) Roma education as a lucrative niche: Ideologies and representations. Zeitschrift für Internationale Bildung und Entwicklungspädagogik, 38:1, 11-17.

McGarry, A. (2010) Who speaks for Roma? Political representation of a transnational minority community. London: Continuum.

McGarry, A (2014) Roma as a political identity: Exploring representations of Roma in Europe. Ethnicities, 14:6, 756-774.

MigRom (2015) Report on the extended survey (University of Manchester). See http:// migrom.humanities.manchester.ac.uk/wp-content/uploads/2015/08/Yr2report_Mcr.pdf.

Nirenberg, J. (2009) Romani political mobilization from the First International Romani Union Congress to the European Roma, Sinti and Travelers Forum. In Sigona, N. \& Trehan, N. (eds) Romani politics in contemporary Europe. Poverty, ethnic mobilization, and the neoliberal order (pp. 94-115). London: Palgrave Macmillan.

O'Keeffe, B. (2013) New Soviet Gypsies: Nationality, performance, and selfhood in the early Soviet Union. Toronto: University of Toronto Press.

Okely, J. (1997) Some political consequences of theories of Gypsy ethnicity. The place of the intellectual. In James, A., Hockey, J., \& Dawson, A. (eds) After writing culture. Epistemology and praxis in contemporary anthropology (pp. 224-243). London: Routledge.

Pontrandolfo, S. (2014) The disappearance of a Rom community and the rejection of the politics of recognition. Journal of Modern Italian Studies, 19:2, 119-131.

Puxon, G. (2000) The Romani movement: Rebirth and the First World Romani Congress in retrospect. In Acton, T. A. (ed.) Scholarship and the Gypsy struggle. Commitment in Romani studies (pp. 94-113). Hatfield: University of Hertfordshire Press.

Ram, M. (2014) Europeanized hypocrisy: Roma inclusion and exclusion in Central and Eastern Europe. Journal on Ethnopolitics and Minority Issues in Europe, 13:3, 15-44.

Rostas, J. (2009) The Romani movement in Romania: Institutionalization and (de)mobilization. In Sigona, N. \& Trehan, N. (eds) Romani politics in contemporary Europe. Poverty, ethnic mobilization, and the neoliberal order. (pp. 159-185). London: Palgrave Macmillan.

Rővid, M. (2011) One-size-fits-all Roma? On the normative dilemmas of the emerging European Roma policy. Romani Studies, 21:1, 1-22.

Sigona, N. \& Trehan, N. (eds) (2009) Romani politics in contemporary Europe. Poverty, ethnic mobilization, and the neoliberal order (pp. 94-115). London: Palgrave Macmillan.

Surdu, M. \& Kovats, M. (2015) Roma identity as an expert-political construction. Social Inclusion, 3:5, 5-18. 
Trehan, N. \& Kóczé, A. (2009) Racism, (neo)-colonialism and social justice: The struggle for the soul of the Romani movement in post-socialist Europe. In Huggan, G. \& Law, I. (eds) Racism, postcolonialism, Europe. (pp. 50-73). Liverpool: Liverpool University Press.

van Baar, H. (2011) Europe's Romaphobia: Problematization, securitization, nomadization. Environment and Planning D: Society and Space, 29, 203-212.

van Baar, H. (2013) Traveling activism and knowledge production in contemporary Romani politics. In Miskovic, M. (ed.) Roma education in Europe. Practices, policies and politics (pp. 191-202). London: Routledge.

van Baar, H. (2015) Enacting memory and the hard labor of identity formation: Rethinking the Romani movement and its historiography. In McGarry, A. \& Jasper, J. A. (eds) The identity dilemma. Social movements and collective identity (pp. 150-167). Philadelphia: Temple University Press.

Vermeersch, P. (2006) The Romani movement: Minority politics and ethnic mobilization in contemporary Central Europe. Oxford: Berghahn. 